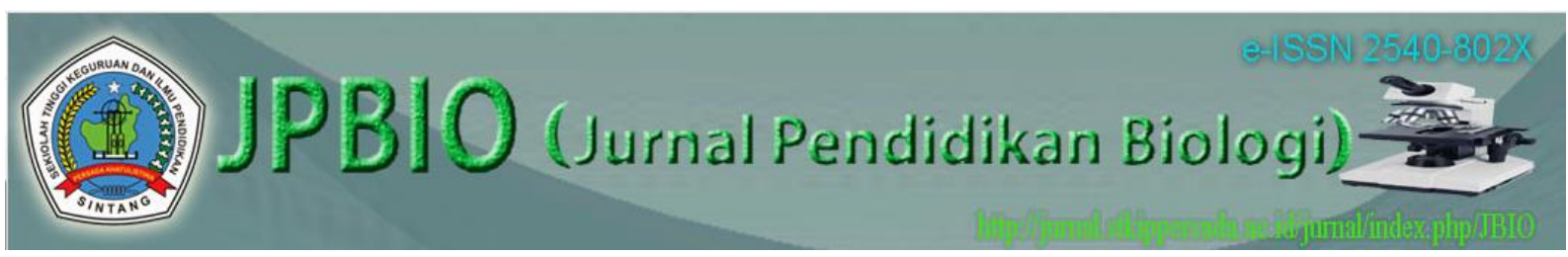

JPBIO (Jurnal Pendidikan Biologi)

Vol. 1 No. 1 November 2016 | 29-39

ISSN 2540-802x (Online)

DOI: http://dx.doi.org/10.31932/JPBIO (Jurnal Pendidikan Biologi)

http://jurnal.stkippersada.ac.id/jurnal/index.php/JBIO

\title{
PENERAPAN MODEL PEMBELAJARAN GROUP INVESTIGATION TERHADAP KEMAMPUAN PEMECAHAN MASALAH SISWA PADA MATERI SISTEM PENCERNAAN PADA MANUSIA
}

\author{
Kristianti Meti Trikasari ${ }^{1}$, Benediktus Ege ${ }^{2^{\star}}$, Markus lyus Supiandi ${ }^{3}$
}

1Mahasiswa Program Studi Pendidikan Biologi, STKIP Persada Khatulistiwa Sintang 2,3Dosen Program Studi Pendidikan Biologi, STKIP Persada Khatulistiwa Sintang

E-mail:metirada24@gmail.com,ama_tamo@yahoo.com*,msupiandi@gmail.com

Diterima: 25 April $2016 \quad$ Direvisi: 27 Mei $2016 \quad$ Disetujui: 20 Oktober 2016

\begin{abstract}
ABSTRAK
Penelitian ini bertujuan untuk mengetahui penerapan model pembelajaran Group Investigation (GI) terhadap kemampuan pemecahan masalah siswa pada materi sistem pencernaan pada manusia.Variabel bebas dalam penelitian ini adalah model pembelajaran Group Investigation (GI)dan variabel terikatnya adalah kemampuan pemecahan masalah siswa. Metode yang diterapkan dalam penelitian ini adalah metode kuantitatif. Bentuk penelitian ini adalah penelitian eksperimen. Bentuk desain quasi eksperimen yang digunakan dalam penelitian ini adalah Nonequivalent Control Group Design. Teknik sampling yang digunakan adalah Sampling Jenuh. Teknik pengumpulan data yang digunakan adalah teknik observasi, teknik pengukuran, dan teknik komunikasi tidak langsung. Alat pengumpulan data yang digunakan adalah Silabus, RPP, LKS, lembar observasi, soal tes, dan angket. Perhitungan hasil kemampuan pemecahan masalah siswa diperoleh nilai rata-rata pretest kelas eksperimen 43,8 sedangkan posttest73,9 dan kelas kontrol nilai rata-rata pretest 43,8 sedangkan posttest60,6. Hasil uji hipotesis pada data posttest didapatkan nilai signifikansi (Asimp. Sig. 2-tailed) sebesar 0,000, dan hasil ini kurang dari 0,05 $(0,000<0,05)$ maka $\mathrm{H}_{\mathrm{a}}$ diterima. Hal ini menunjukkan bahwa terdapat perbedaanyang signifikan kemampuan pemecahan masalah siswa pada materi sistem pencernaan pada manusia antara kelas eksperimen dan kelas kontrol di kelas VIII SMP Negeri 2 Belimbing Hulu. Hasil analisis angket diperoleh rata-rata nilai $98,58 \%$ dengan kategori sangat kuat.
\end{abstract}

Kata kunci: Model Pembelajaran Group Investigation (GI), Kemampuan Pemecahan Masalah

\section{ABSTRACT}

This study aimed to determine the application of Group Investigation (GI) learning model to the problem solving ability of students in the human digestive systems material. Independent variable in this research was Group Investigation (Gl) learning model and the dependent variable is the students' problem-solving abilities. The method applied in this research was quantitative method in form of experimental research. Quasi experimental research design used in this study was Nonequivalent control group design. The sampling technique used 
was saturated sampling. While, data collection techniques used were observation, measurement techniques, and indirect communication. Data collection tool used were the syllabus, lesson plans, worksheets, observation sheets, questions test, and questionnaires. The calculation of students' problem solving ability obtained an average value on pretest on the experimental class 43.8, and on the posttest 73.9, while the control class average value pretest 43.8 and posttest 60.6. Results of the hypothesis test obtained in the posttest significant value (Asimp. Sig. 2-tailed) of 0.000 , and the result is less than $0.05(0.000<0.05)$, then $\mathrm{Ha}$ accepted. This shows that there was a significant difference in the students' problem-solving abilities in the human digestive system material between the experimental class and the control class in Grade VIII State Junior High School 2 Belimbing Hulu. The results of questionnaire analysis obtained an average $98,58 \%$ with avery strong category.

\section{Keywords: Group Investigation (GI) Learning Model, Problem Solving Ability}

\section{PENDAHULUAN}

Pada abad ke-21 kita semakin dihadapkan pada tuntutan akan pentingnya sumber daya manusia (SDM) yang berkualitas serta mampu berkompetisi. Tuntutan ini dikarenakan kemajuan zaman pada abad ke-21 sudah semakin pesat dan telah menimbulkan persaingan yang keras untuk dapat bertahan hidup. Perubahan juga tampak pada semua aspek kehidupan terutama dalam bidang pendidikan. Menurut Tan, (Widayati, 2015: 53) "pendidikan di abad 21 menekankan pada pengembangan intelektual. Pengembangan intelektual adalah tentang memecahkan masalah pada dunia nyata atau kontekstual yang melibatkan diri dalam berbagai jalan untuk mengetahui dan belajar". Pengembangan intelektual yang baik akan menciptakan sumber daya manusia (SDM) yang berkualitas pula, hal ini perlu dibentuk dari proses pembelajaran didalam pendidikan.

Pendidikan adalah wadah utama pembentukan manusia, kualitas pendidikan adalah sasaran utama untuk menjawab tuntutan abad ini, pendidikan yang berkualitas pasti akan menciptakan manusia yang berkualitas pula. Menurut Rusman, (2012: 230) "pendidikan bukan hanya menyiapkan masa depan, tetapi juga bagaimana menciptakan masa depan". Dalam hal ini pendidikan harus mampu mengembangkan potensi peserta didik, membentuk individu yang kritis dengan keterampilan berpikir yang tinggi sehingga yang bersangkutan mampu menghadapi dan memecahkan problema kehidupan yang dihadapinya. Kenyataan yang terjadi, hingga saat ini dunia pendidikan kita masih tidak lepas dari permasalahan. Permasalahan yang kerap kali dihadapi adalah kualitas hasil pendidikan disegenap jenjang dan jalur pendidikan yang masih belum memuaskan, hal ini terjadi salah satunya karena masih lemahnya proses pembelajaran.

Pembelajaran merupakan bagian atau elemen yang memiliki peran sangat dominan untuk menunjukan kualitas baik proses maupun lulusan (output) pendidikan. Pembelajaran juga memiliki pengaruh yang menyebabkan rendahnya kualitas pendidikan. Hal ini juga berakibat sulitnya menghasilkan pribadi yang terampil, mandiri, dan mampu dalam memecahkan berbagai masalah. Menurut Widayati, (2015: 53) "pendidikan di abad pengetahuan diharapkan sudah menerapkan kemampuan memecahkan masalah".

Kemampuan pemecahan masalah dalam hal ini perlu dilatih agar siswa menjadi terampil dalam memecahkan setiap masalah, baik untuk keperluan jangka pendek maupun untuk jangka panjang sebagai bekal untuk kehidupannya di masyarakat. Dalam hal ini guru juga hendaknya lebih banyak memberikan kesempatan kepada siswa untuk belajar bagaimana memecahkan masalah. Melalui pembelajaran yang dirancang dengan baik diharapkan kemampuan tersebut dapat dengan cepat dan lebih mudah dikuasai siswa, sehingga siswa tidak hanya menguasai kosep pembelajaran akan tetapi mampu menerapkan konsep tersebut dalam menyelesaikan masalah dikehidupan sehari-hari.

Berdasarkan hasil pra-observasi dengan guru mata pelajaran Imu Pengetahuan Alam, yang dilakukan di Sekolah Menengah Pertama Negeri 2 Belimbing Hulu pada hari Kamis tanggal 28 Maret 2016 pukul 09.00-10.30 WIB didapatkan bahwa, siswa belum terlatih dalam memecahkan masalah atau dalam artian, kemampuan pemecahan masalah siswa belum 
maksimal. Hal ini didasari karena siswa cenderung sulit untuk bernalar dan mengemukakan pendapat menggunakan logika, kebingungan, serta mengalami kesulitan ketika diminta berargumen memecahkan masalah dalam proses pembelajaran. Kebanyakan dari siswa lebih memilih diam dan tidak menanggapi ketika diminta untuk mengeluarkan pendapat, begitu juga ketika siswa diminta berdiskusi dengan teman sekelompok cenderung hanya beberapa siswa yang aktif, sedangkan yang lainnya hanya diam dan menunggu hasil. Hal ini tampak pula ketika siswa menjawab soal, siswa cenderung menjawab soal dengan benar jika soal yang mereka terima sama persis dengan yang ada di buku paket.

Masalah ini jelas menunjukkan bahwa siswa belum memiliki keterampilan dan kemampuan dalam memecahkan masalah. Hal ini terjadi karena proses pembelajaran yang dilakukan masih didominasi dengan penggunaan metode ceramah yang kegiatannya lebih terpusat pada guru. Siswa mengalami kesulitan dalam memahami materi pembelajaran karena aktivitas siswa dapat dikatakan hanya mendengar penjelasan dari guru dan mencatat hal-hal yang dianggap penting.

Berdasarkan permasalahan tersebut, maka perlu adanya suatu inovasi dalam melaksanakan proses pembelajaran. Inovasi dimana pembelajaran dapat menumbuhkembangkan kemampuan pemecahan masalah siswa dan kegiatan pembelajaran yang lebih berpusat pada siswa sehingga pengembangan intelektual dan sumber daya siswa dapat terbentuk. Perubahan yang dapat dilakukan adalah dengan cara mempelajari dan mempraktikan berbagai model-model dalam proses pembelajaran. Model Pembelajaran merupakan alat untuk mencapai tujuan pengajaran yang ingin dicapai sehingga semakin baik penggunaan model pembelajaran semakin berhasil pencapaian tujuan belajar. Rusman, (2012: 229) menyatakan bahwa "guru dituntut dapat memilih model pembelajaran yang dapat memacu semangat setiap siswa untuk secara aktif terlibat dalam pengalaman belajarnya". Dalam hal ini dimaksudkan guru diharapkan mampu memilih model pembelajaran yang sesuai dengan materi yang diajarkan. Pemilihan model pembelajaran sebaiknya dilakukan dengan mempertimbangkan situasi dan kondisi, sumber belajar, kebutuhan, dan karakteristik peserta didik yang dihadapi dalam rangka mencapai tujuan pembelajaran tertentu. Salah satu inovasi pembelajaran yaitu dengan menggunakan model pembelajaran kooperatif (cooperative learning).

Menurut Eggen dan Kauchak (Trianto, 2011: 58) mengungkapkan bahwa, "pembelajaran kooperatif merupakan sebuah kelompok strategi pengajaran yang melibatkan siswa bekerja secara berkolaborasi, untuk mencapai tujuan bersama". Pembelajaran kooperatif mengupayakan peserta didik mampu mengajarkan sesuatu kepada peserta didik lainnya, mengajar teman sebaya, memberikan kesempatan pada peserta didik untuk mempelajari sesuatu dengan baik pada waktu bersamaan. Kondisi ini dapat mendorong (memotivasi) siswa untuk belajar, bekerja, dan bertanggung jawab dalam mencapai tujuan pembelajaran. Ada beberapa macam model pembelajaran kooperatif salah satunya adalah model Group Investigation (GI).

Trianto, (2011: 59) "Group Investigation (GI) merupakan salah satu tipe pembelajaran kooperatif yang paling kompleks dan paling sulit untuk diterapkan. Siswa dilibatkan dalam perencanaan baik topik yang dipelajari dan bagaimana jalannya penyelidikan mereka". Model ini mengajarkan kepada siswa dalam komunikasi kelompok dan proses kelompok yang baik. Primarindha, (2012: 62) "pada dasarnya model ini dirancang untuk membimbing para siswa mendefinisikan masalah, mengeksplorasi mengenai masalah, mengumpulkan data yang relevan, mengembangkan dan menguji hipotesis". Dengan model pembelajaran Group Investigation (GI) yang dimulai dengan masalah, siswa dilatih untuk menumbuhkan kemampuan berpikir mandiri, terlibat secara aktif pada pembelajaran mulai dari tahap pertama sampai tahap akhir, dan memiliki kreatifitas dalam mencari solusi setiap permasalahan, sehingga dapat memberi peluang kepada siswa untuk lebih mempertajam gagasan.

Berdasarkan hasil penelitian terdahulu tentang penggunaan model pembelajaran Group Investigation (GI), Sarmin (2014) menyimpulkan "terdapat perbedaan yang signifikan antara variabel bebas $(\mathrm{X})$ model pembelajaran cooperative learning tipe Group Investigation (GI) dengan variabel terikat $(Y)$ Kemampuan pemecahan masalah siswa, dengan demikian 
Ha diterima $\mathrm{H}_{0}$ ditolak". Hal ini diperkuat dengan hasil penelitian yang dilakukan Muhandas (2015)menyimpulkan bahwa, kemampuan pemecahan masalah matematis siswa yang diajar dengan model kooperatif tipe Group Investigation (GI) lebih baik secara signifikan dari pada siswa yang diajar dengan pembelajaran konvensional.

Bertitik tolak dari uraian tersebut maka penulis berkeinginan untuk melakukan penelitian eksperimen dengan judul "Penerapan Model Pembelajaran Group Investigation (Gl)terhadap Kemampuan Pemecahan Masalah Siswa pada Materi Sistem Pencernaan pada Manusia (Studi Eksperimen di kelas VIII Sekolah Menengah PertamaNegeri 2 Belimbing Hulu Tahun Pelajaran 2016/2017)".

\section{METODE PENELITIAN}

Metode penelitian yang digunakan dalam penelitian ini adalah metode penelitian eksperimen. Menurut Sugiyono, (2008: 72) "metode penelitian eksperimen adalah metode penelitian yang digunakan untuk mencari pengaruh perlakuan tertentu terhadap yang lain dalam kondisi yang terkendalikan".Bentuk penelitian eksperimen yang digunakan adalah quasi eksperimenyaitu penelitian yang tidak mengontrol secara penuh variabel dari luar. Sukmadinata, (2012: 59) mengemukakan bahwa, "pengontrolan variabel dilakukan terhadap satu variabel saja, yaitu variabel yang dianggap paling dominan". Adapun Rancangan yang digunakan yaitu, Nonequivalent Control Group Design. Teknik sampel yang digunakan yaitu sampling jenuh. "Sampling jenuh adalah teknik penentuan sampel bila semua anggota populasi digunakan sebagai sampel” (Sugiyono, 2013: 68).

\section{HASIL PENELITIAN}

\section{Hasil Observasi Aktivitas Guru dan Siswa Kelas Eksperimen}

Observasi Guru kelas eksperimen dilakukan pada saat berlangsungnya penerapan model pembelajaran Group Investigation (GI) dalam proses pembelajaran pada materi sistem pencernaan pada manusia.Peneliti dibantu rekan dalam melakukan observasi. Hasil observasi guru dan siswa pada pertemuan pertama diperoleh $100 \%$, pada pertemuan kedua juga diperoleh $100 \%$, sehingga rata-rata kedua pertemuan yaitu $100 \%$.

\section{Rata-rata Pencapaian Indikator Kemampuan Pemecahan Masalah Siswa pada Pretest dan Posttest Kelas Eksperimen dan Kontrol}

Pretest dan posttest kemampuan pemecahan masalah meliputi lima soal setiap topik berdasarkan lima indikator pemecahan masalah. Rangkuman hasil rata-rata indikator kemampuan pemecahan masalah siswa pada pretest dan posttestdapat dilihat pada Tabel 1. Tabel 1. Rata-rata Pencapaian Indiktor Kemampuan Pemecaham Masalah Siswa

\begin{tabular}{llllll}
\hline No & \multicolumn{1}{c}{ Indikator KPM } & \multicolumn{2}{c}{ Kelas Eksperimen } & \multicolumn{2}{c}{ Kelas Kontrol } \\
& Pretest & Posttest & \multicolumn{1}{c}{ Pretest } & Posttest \\
\hline 1 & MerumuskanMasalah & 83,80 & 97,22 & 75,93 & 90,74 \\
2 & MerumuskanHipotesis & 70,37 & 96,76 & 76,39 & 90,28 \\
3 & Mengumpulkan Data & 11,11 & 51,39 & 13,43 & 23,61 \\
4 & MerekomendasikanPemecahanM & & & & \\
& asalah & 30,09 & 61,57 & 34,72 & 51,85 \\
5 & MenarikKesimpulan & 23,61 & 62,50 & 18,52 & 46,30 \\
Rata-Rata Keseluruhan & $\mathbf{4 3 , 8}$ & $\mathbf{7 3 , 9}$ & $\mathbf{4 3 , 8}$ & $\mathbf{6 0 , 6}$ \\
\hline Selisih & \multicolumn{3}{c}{$\mathbf{3 0 . 1}$} \\
\hline
\end{tabular}

\section{Hasil Kemampuan Pemecahan Masalah Siswa Sebelum dan Setelah Pembelajaran di Kelas Kontrol (Pretest dan Posttest)}

Sebelum sampel penelitian diberikan perlakuan, terlebih dahulu guru memberikan tes awal (pretest) kepada siswa kelas VIII B sebagai kelas kontrol yang berjumlah 18 orang. Hasil analisis kemampuan pemecahan masalah siswa kelas kontrol pada pretest diperoleh dengan nilai tertinggi 58,3 dan nilai terendah 21,7 dengan rata-rata 43,8 . Pada 
posttest diperoleh dengan nilai tertinggi 70,0 dan nilai terendah 51,7 dengan rata-rata sebesar 60,6.

\section{Hasil Kemampuan Pemecahan Masalah Siswa Sebelum dan Setelah Pembelajaran di Kelas Eksperimen (Pretest dan Posttest)}

Sebelum sampel penelitian diberi perlakuan, terlebih dahulu guru memberikan tes awal (pretest) kepada siswa kelas VIII A sebagai kelas eksperimen yang berjumlah 18 orang. hasil kemampuan pemecahan masalah siswa kelas eksperimen pada pretest diperoleh dengan nilai tertinggi 66,7 dan nilai terendah 13,3 dengan rata-rata sebesar 43,8. Pada posttest diperoleh dengan nilai tertinggi 93,3 dan nilai terendah 55,0 dengan rata-rata posttest sebesar 73.9.

\section{Hasil Perbedaan Kemampuan Kemampuan Pemecahan Siswa di Kelas Eksperimen dan Kelas Kontrol}

Sebelum dilakukan uji hipotesis, peneliti terlebih dahulu melakukan uji normalitas data. Uji normalitas data bertujuan untuk melihat apakah data berdistribusi normal atau berdistribusi tidak normal. Pada penelitian ini, uji normalitas data menggunakan program SPSS 20 dengan uji Kolmogorov-Smirnov dengan taraf kepercayaan $\alpha=5 \%(0,05)$. Hasil uji normalitas data dapat dilihat pada Tabel 1.

Tabel 2. Hasil Uji Normalitas Kelas Eksperimen dan Kelas Kontrol

\begin{tabular}{llllll}
\hline & A & $\begin{array}{c}\text { Pretest } \\
\text { Kontrol }\end{array}$ & $\begin{array}{c}\text { Pretest } \\
\text { Eksperimen }\end{array}$ & $\begin{array}{c}\text { Posttest } \\
\text { Kontrol }\end{array}$ & \multicolumn{1}{c}{$\begin{array}{c}\text { Posttest } \\
\text { Eksperimen }\end{array}$} \\
\hline $\mathrm{N}$ & & 18 & 18 & 18 & 18 \\
Mean & 43,7956 & 43,7978 & 60,5550 & 73,8883 \\
Std.Deviasi & 0,05 & 9,79722 & 13,31868 & 4,50134 & 10,12962 \\
Nilai hitung & & 0.200 & 0.200 & 0,200 & 0,200 \\
Kesimpulan & & Normal & Normal & Normal & Normal \\
\hline
\end{tabular}

Selanjutnya peneliti melakukan uji homogenitas data, uji homogenitas data dalam penelitian ini menggunakan uji levene atau Kolmogorov-Smirnov. Hasil uji homogenitas data dapat dilihat pada Tabel 2.

Tabel 3. Hasil Uji Homogenitas Pretest dan Posttest Kelas Eksperimen dan Kelas Kontrol

\begin{tabular}{llllll}
\hline No & Data yang diuji & $\begin{array}{l}\text { Nilai } \\
\text { Hitung }\end{array}$ & $\begin{array}{l}\text { Signifikansi } \\
(\alpha)\end{array}$ & $\begin{array}{l}\text { Jumlah } \\
\text { Data }\end{array}$ & Kesimpulan \\
\hline 1. & $\begin{array}{l}\text { Pretest Kelas Eksperimen } \\
\text { dan Kelas Kontrol }\end{array}$ & 0,370 & 0,05 & 36 & Data Homogen \\
$\begin{array}{l}\text { 2. } \\
\begin{array}{l}\text { Posttest Kelas Eksperimen } \\
\text { dan kelas Kontrol }\end{array}\end{array}$ & 0.003 & 0,05 & 36 & Tidak Homogen \\
\hline
\end{tabular}

Berdasarkan hasil uji normalitas dan homogenitas data, maka uji hipotesis menggunakan statistik parametrik yaitu uji Independent Samples Test (SPSS. 20). Sampel yang digunakan oleh peneliti sebanyak 18 siswa pada kelas eksperimen dan 18 siswa pada kelas kontrol. Hasil uji Independent Samples Test (SPSS. 20) pada data pretest dapat dilihat pada Tabel 3. 
Tabel 4. Hasil Uji Hipotesis Pretest dengan Uji Independent Samples Test

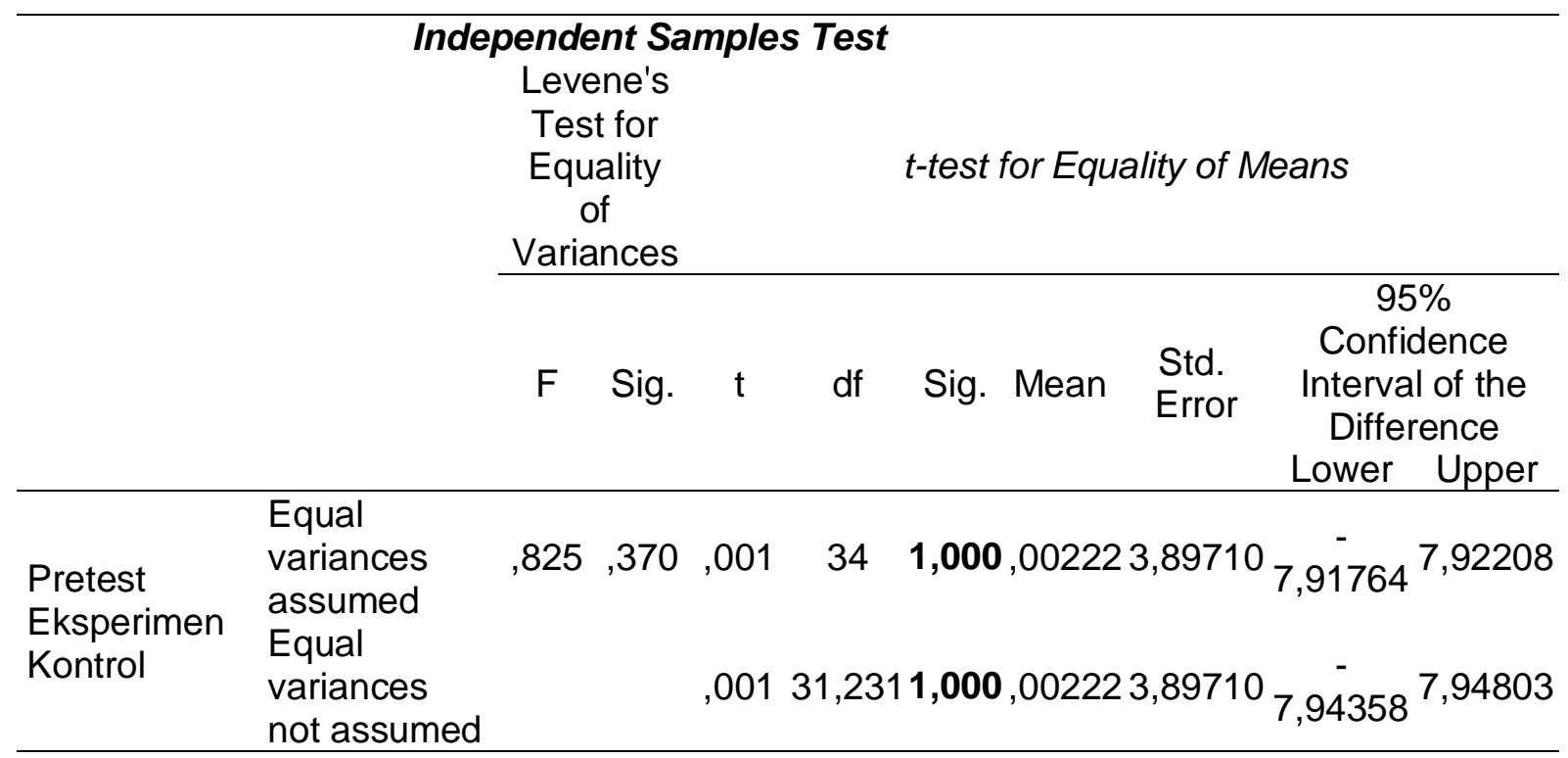

Dilihat dari hasil uji Independent Samples Testmenunjukkan nilai signifikansi (Asimp. Sig. 2-tailed) sebesar 1,000 dan hasil ini lebih dari 0,05 (1,000>0,05), maka $\mathrm{H}_{0}$ diterima yaitu tidak terdapat perbedaan yang signifikan kemampuan pemecahan masalah siswa antara kelas kontrol dan kelas eksperimen pada materi sistem pencernaan pada manusia di kelas VIII SMP Negeri 2 Belimbing Hulu.

Sedangkanuji hipotesis pada data posttest peneliti juga menggunakan uji parametrik yaitu Uji Independent Samples Test. Sampel yang digunakan oleh peneliti sebanyak 18 siswa pada kelas eksperimen dan 18 siswa pada kelas kontrol. Hasil uji Independent Samples Test dapat dilihat pada Tabel 4.

Tabel 5. Hasil Uji Hipotesis Posttest dengan Uji U Mann Whithey

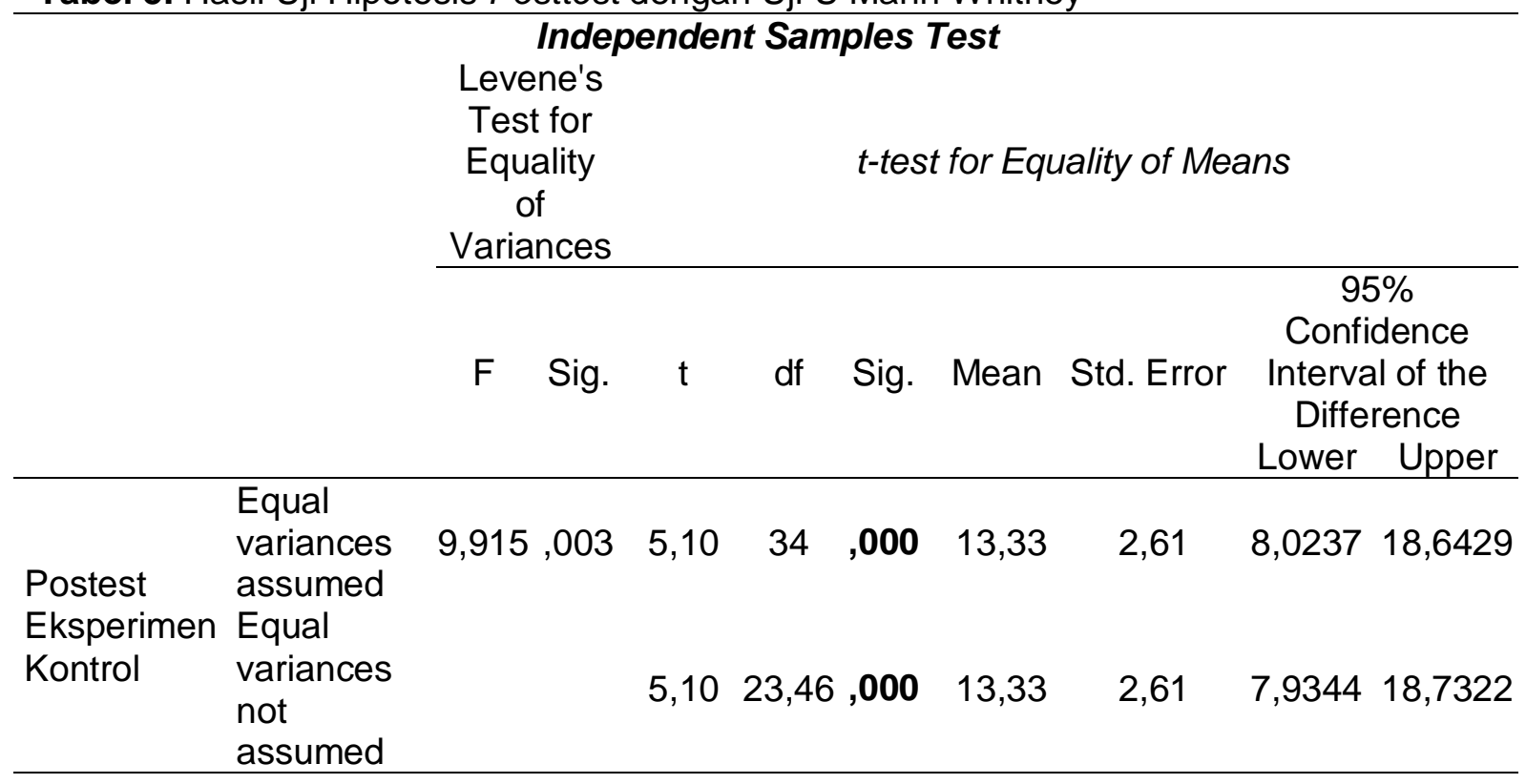




\section{Hasil Respon Siswa}

Menurut Sugiyono (2013: 142) "Angket merupakan daftar pertanyaan yang harus diisi oleh subyek penelitian atau responden untuk dijawab". Tujuan menyebarkan lembar angket yaitu untuk mengetahui respon siswa setelah pembelajaran dengan menggunakan model pembelajaran Group Investigation (GI) pada materi sistem pencernaan pada manusia di kelas VIIIA. Angket disebarkan setelah melaksanakan tes akhir (posttest).Hasil analisis angket respon siswa dapat dilihat pada Tabel 5.

Tabel 6. Hasil Angket Respon Siswa

\begin{tabular}{ccc}
\hline $\begin{array}{c}\text { Jumlah } \\
\text { Pernyataan }\end{array}$ & Rata-rata Persentase & Kriteria Penilaian \\
\hline 25 & $98,58 \%$ & Sangat Kuat \\
\hline
\end{tabular}

\section{PEMBAHASAN}

\section{Observasi Guru dan Siswa di Kelas Eksperimen}

Berdasarkan analisis observasi guru dan siswa pada pertemuan pertama dan kedua, didapat rata-rata persentase pelaksanaan 100\% dengan kriteria "Baik". Artinya guru telah melaksanakan pembelajaran mulai dari pendahuluan sampai penutup pembelajaran sesuai dengan rangkaian kegiatan pembelajaran yang terdapat pada langkah-langkah penerapan model pembelajaran Group Investigation (GI) dan siswa juga telah mengikuti pembelajaran mulai dari pendahuluan sampai akhir pembelajaran dengan baik.

\section{Kemampuan Pemecahan Masalah Siswa Sebelum dan Setelah Pembelajaran (Pretest dan Posttest) Kelas Eksperimen dan Kontrol}

Berdasarkan pengujian hipotesis kemampuan pemecahan masalah pada posttest menunjukkan bahwa nilai signifikansi (Asim. Sig. 2-tailed $)<0,05$ yakni $(0,000<0,05)$ dan dinyatakan berbeda signifikan. Pengujian hipotesis tersebut membuktikan bahwa Ho ditolak dan $\mathrm{Ha}$ diterima yakni; terdapat perbedaan yang signifikan kemampuan pemecahan masalah siswa antara kelas eksperimen dan kelas kontrol pada materi sistem pencernaan pada manusia di kelas VIII Sekolah Menengah Pertama Negeri 2 Belimbing Hulu, sehingga dapat dikatakan bahwa sesudah diterapkan model pembelajaran Group Investigation (Gl), kemampuan pemecahan masalah siswa mengalami perbedaan yang signifikan.

Selain dilakukan analisis hasil pretest dan posttest kemampuan pemecahan masalah siswa, pada penelitian ini juga dilakukan analisis rata-rata pencapaian indikator kemampuan pemecahan masalah siswa pada pretest dan posttest di kelas yang menerapkan model pembelajaran Group Investigation (Gl) yakni kelas eksperimen, dan kelas yang menggunakan pembelajaran konvensional yakni kelas kontrol.

Berdasarkan Tabel 1 didapatkan bahwa indikator tertinggi yang dicapai oleh siswa dalam pemecahan masalah adalah indikator pertama yaitu merumuskan masalah, hal ini karena pada proses pembelajaran siswa dibiasakan dalam merumuskan masalah, dengan demikian siswa telah memahami maksud dari masalah kemudian memahami bagaimana merumuskan masalah secara tepat. Indikator paling rendah yang dicapai siswa dalam proses pemecahan masalah adalah indikator ketiga yaitu mengumpulkan data, hal ini karena pada kegiatan pembelajaran siswa masih merasa kesulitan dalam mencari informasi yang sesuai yang perlu dikumpulkan untuk memecahkan suatu masalah. Hal ini juga didasarkan akan kurangnya pengalaman dan pengetahuan siswa.

Hasil rata-rata pencapaian indikator pemecahan masalah siswa pada kelas yang menggunakan model pembelajaran Group Investigation (GI) lebih tinggi dibandingkan dengan kelas yang menggunakan pembelajaran konvensional, dengan selisih pada kelas eksperimen sebesar 30,1 dan pada kelas kontrol 16,8. Hal ini membuktikan bahwa model pembelajaran Group Investigation (Gl) dapat melatih siswa dalam memecahkan masalah, 
didasari oleh langkah Group Investigation (Gl) yang mengarah pada proses pemecahan masalah dan adanya diskusi kelompok dengan topik masalah yang berbeda, siswa lebih banyak mengumpulkan gagasan/ide serta pendapat dari anggota kelompok untuk memecahkan masalah. Dengan topik masalah yang berbeda pula semakin melatih siswa untuk memiliki pengalaman dan pengetahuan yang luas tentang hal memecahkan masalah. Pada pembelajaran konvensional siswa tidak terlatih dalam memecahkan masalah, karena dalam kegiatan pembelajarannya, siswa tidak dibentuk secara kelompok untuk memecahkan masalah, namun siswa hanya diberikan satu topik masalah untuk keseluruhan kelas sehingga dalam hal ini siswa kurang memiliki pengalaman dan kurang mengekspor pengetahuannya untuk memecahkan masalah.

Hasil penelitian ditemukan bahwa terdapat perbedaan kemampuan pemecahan masalah siswa pada materi sistem pencernaan pada manusia antara siswa yang belajar dengan menggunakan model pembelajaran Group Investigation (GI) dengan siswa yang belajar dengan model pembelajaran konvensional. Hal itu dikarenakan proses pembelajaran Group Investigation (GI) lebih menekankan pada partisipasi siswa secara aktif dalam menentukan topik bahasan, menginvestigasi masalah, menganalisis hasil temuan dan menyampaikan hasil temuan. Model pembelajaran ini dapat meningkatkan aktivitas dan partisipasi siswa untuk mencari sendiri materi (informasi) dengan menggunakan bantuan berbagai sumber belajar seperti buku pembelajaran yang relevan maupun dengan menggunakan sumber-sumber yang lain. Hal ini sejalan dengan pendapat Arifin dan Afandi (2015: 13) yang mengungkapkan bahwa

Group Investigation merupakan pembelajaran dimana siswa dilibatkan sejak perencanaan, baik dalam menentukan topik/sub topik maupun cara untuk pembelajaran secara investigasi dan model ini menuntut para siswa memiliki kemampuan berkomunikasi dengan baik dalam arti bahwa pembelajaran investigasi kelompok itu metode yang menekankan pada partisipasi dan aktivitas siswa untuk mencari sendiri materi (informan) pelajaran yang akan dipelajari melalui bahan-bahan yang tersedia misalnya dari buku pelajaran, masyarakat, internet.

Model pembelajaran Group Investigation (Gl) memiliki enam tahap proses pembelajaran yaitu: mengidentifikasi topik dan mengorganisasikan siswa ke dalam kelompok, merencanakan tugas-tugas belajar, melaksanakan investigasi, menyiapkan laporan akhir, mempresentasikan laporan akhir, danevaluasi. Salah satu tahap Group Investigation (Gl) yang sangat memberi pengaruh terhadap kemampuan pemecahan masalah siswa adalah melaksanakan investigasi, karena dalam tahap melaksanakan investigasi, siswa mengumpulkan fakta-fakta dari berbagai sumber yaitu melalui buku pembelajaran yang relevan untuk menganalisis topik masalah yang mereka pilih, kemudian anggota kelompok membahas topik masalah dengan saling bertukar pendapat, berdiskusi, mengklarifikasi dan menganalisis semua gagasan/ide yang ada pada kelompok untuk dipahami lalu menemukan dan menentukan cara atau solusi untuk memecahkan atau menyelesaikan masalah tersebut. Hal ini sejalan dengan pendapat Setiawan dalam Muhandas (2015: 42) yang mengatakan bahwa, "investigasi mendorong siswa untuk belajar lebih aktif dan lebih bermakna artinya siswa dituntut selalu berpikir tentang suatu persoalan dan mereka mencari sendiri cara penyelesaiannya, dengan demikian mereka akan lebih terlatih untuk menggunakan keterampilan mereka dalam menyelesaikan suatu masalah.

Kegiatan pada langkah melaksanakan investigasi, antara lain siswa mencari informasi, menganalisis data, dan membuat kesimpulan kelompok, sehingga dalam hal ini, siswa sendiri yang dituntut lebih aktif berpikir untuk mencari suatu penyelesaian dari suatu masalah dengan memunculkan kemungkinan-kemungkinan solusi yang sesuai dengan masalah kemudian ditarik kesimpulan solusi yang tepat yang akan digunakan untuk mengatasi masalah. Dengan demikian siswa memiliki pengalaman menemukan sendiri konsep penyelesaian dari masalah yang telah mereka bahas. Pengalaman menemukan sendiri konsep penyelesaian masalah dapat membuat pemahaman siswa 
lebih baik sehingga siswa lebih mengerti lebih paham dan sulit untuk dilupakan. Hal ini sejalan dengan pendapat Bruner dalam Muhandas (2015:42) yang mengatakan bahwa "siswa hendaknya belajar melalui partisipasi secara aktif dengan konsep dan prinsipprinsip dan mereka dianjurkan untuk memperoleh pengalaman dan melakukan eksperimen-eksperimen yang mengizinkan mereka menemukan prinsip-prinsip itu sendiri". Temuan pada penelitian ini didasarkan pula oleh pendapat Slavin, (Rusman, 2012: 221) mengemukakan bahwa,

belajar kooperatif dengan teknik Group Investigation (GI), sangat cocok untuk bidang kajian yang memerlukan kegiatan studi proyek terintegrasi yang mengarah pada kegiatan perolehan, analisis, dan sintetis informasi dalam upaya untuk memecahkan suatu masalah. Strategi belajar kooperatif Gl sangatlah ideal diterapkan dalam pembelajaran biologi (IPA). Dengan topik materi IPA yang cukup luas dan desain tugastugas atau sub-sub topik yang mengarah kepada kegiatan metode ilmiah, diharapkan siswa dalam kelompoknya dapat saling memberi kontribusi berdasarkan pengalaman sehari-harinya.

Selain didukung oleh beberapa pendapat, penelitian ini juga didukung oleh beberapa hasil penelitian sebelumnya yaituPenelitian yang dilakukan oleh Sarmin (2015) dengan judul "Penerapan Model Cooperatif Learning tipe Group Investigation terhadap Kemampuan Pemecahan Masalah Siswa pada Materi Ekosistem di Kelas X Madrasah Aliyah Saitulmal Pancasila Nanga Pinoh Tahun Pelajaran 2014/2015", membuktikan bahwa terdapat perbedaan yang signifikan antara rata-rata kemampuan pemecahan masalah siswa yang menggunakan Model Cooperatif Learning tipe Group Investigation (GI) dengan siswa yang menggunakan model pembelajaran konvensional dibuktikan dengan uji $U$ Mann Whitney dengan taraf signifikan 5\% diperoleh $Z_{\text {hitung }}$ sebesar $-4,86$ dengan $Z_{\text {tabel }}$ sebesar $-1,96$ sehingga nilai $-Z_{\text {hitung }}>-Z_{\text {tabel }}(-4,86>-1,96)$.

Penelitian lain juga pernah dilakukan oleh Muhandas (2015) dengan judul "Pengaruh Model Pembelajaran Kooperatif tipe Investigasi Kelompok terhadap Pemecahan Masalah Matematis Siswa Kelas VIII MTsN Kota Padang", membuktikan bahwa, kemampuan pemecahan masalah matematis siswa baik secara keseluruhan maupun berdasarkan kemampuan awal tinggi, sedang dan rendah yang diajar dengan model pembelajaran kooperatif tipe investigasi lebih baik dari pada siswa yang diajar dengan model pembelajaran konvensional. Dibuktikan oleh hasil uji hipotesis dengan taraf signifikan 5\% didapat untuk kemampuan awal tinggi sebesar sig. 0,001, kemampuan awal sedang yaitu sig. 0,000 dan kemampuan awal rendah sig. 0,001. Dengan demikian hasil sig kemampuan awal tinggi, sedang, dan rendah $<0,05$.

Berdasarkan beberapa penelitian yang pernah dilakukan, oleh karena itu peneliti tertarik memadukan penelitian tersebut menjadi sebuah penelitian yang baru. Setelah peneliti melakukan perhitungan secara statistik pada data posttest diperoleh hasil yang baik. Maka dari itu dapat disimpulkan bahwa "Terdapat perbedaan yang singnifikan kemampuan pemecahan masalah siswa antara kelas eksperimen dan kelas kontrol pada materi sistem pencernaan pada manusia di kelas VIII Sekolah Menengah Pertama Negeri 2 Belimbing Hulu.

\section{Respon Siswa}

Persentase respon siswa secara keseluruhan adalah $98,58 \%$ berkriteria sangat kuat karena berada pada rentang $81 \%-100 \%$. Dapat disimpulkan bahwa respon siswa setelah proses pembelajaran dengan model Group Investigation (GI)bernilai positif, yang artinya siswa sangat tertarik dengan model yang diterapkan. Hal ini relevan dengan penelitian Sarmin (2015) yang menyatakan bahwa "Hasil analisis respon siswa terhadap pembelajaran model Group Investigation (GI) adalah positif", dengan presentase rata-rata angket siswa adalah $90,8 \%$ 


\section{SIMPULAN}

Berdasarkan dari hasil penelitian yang telah dilaksanakan, dapat disimpulkan bahwa "penerapan model pembelajaran Group Investigation (Gl)memberikan hasil yang lebih baik terhadap kemampuan pemecahan masalah siswa pada materi sistem pencernaan pada manusia di kelas VIII Sekolah Menengah Pertama Negeri 2 Belimbing Hulu tahun pelajaran 2016/2017". Berdasarkan sub masalah penelitian, maka dapat disimpulkan halhal sebagai berikut: (1) Aktivitas guru dalam mengajar dengan menggunakan model pembelajaran konvensional di kelas kontrol berlangsung dengan baik dengan presentase untuk kedua pertemuan sebesar $94,12 \%$ berkriteria baik (B), sementara itu, aktivitas belajar siswa di kelas kontrol dengan menggunakan model pembelajaran konvensional berlangsung dengan kategori baik dengan persentase rata-rata pertemuan pertama dan kedua sebesar 100\%; (2) Aktivitas guru di kelas eksperimen dengan menggunakan model pembelajaran Group Investigation (Gl) berlangsung dengan baik, dengan persentase rata-rata pertemuan pertama dan kedua di kelas eksperimen adalah $100 \%$, dan masuk pada kriteria baik (B). Kemudian untuk aktivitas belajar siswa di kelas eksperimen dengan menggunakan model pembelajaran Group Investigation (Gl) berlangsung dengan kategori baik pula, dengan persentase rata-rata pertemuan pertama dan kedua sebesar $100 \%$; (3) Kemampuan pemecahan masalah siswa sebelum dan sesudah pembelajaran tanpa menggunakan model pembelajaran Group Investigation (GI) adalah 58,3 untuk nilai tertinggi pada pretest dan 21,7 nilai terendah pada pretest dengan rata-rata pengukuran awal sebelum pembelajaran (Pretest)sebesar 43,8. Pada posttest didapat nilai tertinggi 70,0 dan nilai terendah pada posttest adalah 51,7 dengan rata-rata pada pengukuran akhir sesudah pembelajaran (Posttest)sebesar 60,6, sehingga diperoleh selisih antara kemampuan pemecahan masalah siswa sebelum dan sesudah pembelajaran menggunakan model pembelajaran konvensional sebesar 16,8; (4) Kemampuan pemecahan masalah siswa sebelum dan sesudah pembelajaran menggunakan model pembelajaran Group Investigation (GI) adalah 66,7 untuk nilai tertinggi pada pretest dan 13,3 nilai terendah pada pretest dengan rata-rata pada pengukuran awal sebelum pembelajaran (Pretest)sebesar 43,8. Pada posttest nilai tertinggi didapat sebesar 93,3 dan nilai terendah adalah 55,0 dengan rata-rata pada pengukuran akhir sesudah pembelajaran (Posttest)sebesar 73,9, sehingga diperoleh selisih antara kemampuan pemecahan masalah siswa sebelum dan sesudah pembelajaran menggunakan model pembelajaran Group Investigation (GI) sebesar 30,1; (5) Terdapat perbedaan yang signifikan kemampuan pemecahan masalah siswa antara kelas eksperimen dan kelas kontrol. Pengujian hipotesis kemampuan pemecahan masalah pada posttest menunjukkan bahwa nilai signifikansi (Asim. Sig. 2-tailed $)<0,05 \quad(0,000<0,05)$. Berdasarkan hasil pengujian hipotesis tersebut dapat disimpulkan bahwa kemampuan pemecahan masalah siswa antara kelas eksperimen dan kelas kontrol pada posttest mengalami perbedaan yang signifikan. Pengujian hipotesis tersebut membuktikan bahwa Ha dapat diterima yakni; terdapat perbedaan yang singnifikan kemampuan pemecahan masalah siswaantara kelas eksperimen dan kelas kontrol pada materi sistem pencernaan pada manusia di kelas VIII Sekolah Menengah Pertama Negeri 2 Belimbing Hulu; (6) Respon siswa setelah menggunakan model pembelajaran Group Investigation (GI) pada materi sistem pencernaan pada manusia di kelas VIII Sekolah Menengah Pertama Negeri 2 Belimbing Hulu berkategori sangat kuat yaitu sebesar 98,58\%, sehingga disimpulkan respon siswa positif terhadap model pembelajaran Group Investigation (GI).

\section{REFERENSI}

Arifin. Z. dan Afandi.Y. (2015). Pengaruh Model Pembelajaran Kooperatif Tipe Investigasi Kelompok (Group Investigation) Dan Strategi StudentTeam Achievement Division (Stad) Terhadap Keterampilan Proses Dan Hasil Belajar Akuntansi Siswa Smk Di Kota Kediri. Jurnal Penelitian Pendidikan. 02(01) 10-25. 
Muhandas. R.( 2015). Pengaruh Model Pembelajaran Kooperatif Tipe Investigasi Kelompok Terhadap Pemecahan Masalah Matematis Siswa Kelas VIII Mtsn Kota Padang. Journal of Mathematics Education. 1 (1) 35-44.

Primarindha. I. dkk. (2012). "Pengaruh Model Pembelajaran Cooperative Learning Tipe Group Investigation (GI) Terhadap Keterampilan Proses Sains Dan Hasil Belajar Biologi Siswa Kelas X Sma Negeri 4 Surakarta Tahun Pelajaran 2011/2012". Jurnal IImu Pendidikan. 4(2) 60-71.

Rusman.( 2012). Model-Model Pembelajaran. Jakarta:Rajawali Pers.

Sarmin. (2014). "Penerapan Model Cooperatif Learning tipe Group Investigation terhadap Kemampuan Pemecahan Masalah Siswa pada Materi Ekosistem di Kelas $X$ Madrasah Aliyah Saitulmal Pancasila Nanga Pinoh tahun Pelajaran 2014/2015". Skripsi tidak diterbitkan. Sintang: STKIP Persada Khatulistiwa Sintang.

Sugiyono. (2008). Metode Penelitian Kuantitatif Kualitatif dan $R \& D$. Bandung: Alfabeta. ------. (2013). Statistika Untuk Penelitian. Bandung: Alfabeta.

Sukmadinata. S. N. (2012). Metode Penelitian Pendidikan. Bandung: Rosda.

Trianto. (2011). Model-model Pembelajaran Inovatif Berorientasi Konstruktivistik. Jakarta: Prestasi Pustaka.

Trianto. (2012). Mendesain Model Pembelajaran Inovatif-Progresif. Jakarta: Kencana.

Widayati. U. T. (2015). Perbedaan Kemampuan Memecahkan Masalah Dan Retensi Menggunakan Model PBL (Problem Based Learning) dan Ceramah Bervariasi Pada Materi Keanekaragaman Hayati Indonesia Siswa Kelas X Mia SMA Negeri 2 Surakarta Tahun Pelajaran 2014/2015. Jurnal Pendidikan Biologi. 04(1) 53-58. 